\title{
MODERNIZME ÇOK YÖNLÜ BİR ELEŞTİRİ VE FRANKFURT OKULU
}

\author{
MODERNISM IS A VERSATILE AND FRANKFURT \\ SCHOLL OF CRITICISM
}

\section{КРИТИКА МОДЕРНИЗМА И ФРАНКФУРТСКАЯ ШКОЛА}

\author{
Sevra FIRINCIOĞULLARI*
}

\begin{abstract}
ÖZ
Bu çalışma Frankfurt Okulunun çalışma ve eleştiri alanlarını tanıtarak, okulun genel yaklaşımı içinden bir modernizm eleştirisi amaçlamaktadır. Çalışma içinde Frankfurt Okulu'nun doğuşuna, okul içindeki düşünürlere ve modernizme yönelik genel eleştiri noktalarına yer verilmiştir. Bunlar aydınlanma, aklın yozlaşması, pozitivizm, kitle endüstrisi, kapitalizm ve totalitarizm eleştirilerini içermektedir. Eleştiri noktalarının tümünün çıkış noktası okul üyelerinin modernizme yönelik yaklaşımlarından köklenmiştir. Çalışma genel olarak Frankfurt Okulu'nun modernizim eleştirisi üzerinden biçimlense de okulun önde gelen isimleri Adorno ve Horkheimer'in görüşleri çalışma içinde geniş yer tutmaktadır.

Anahtar Kelimeler: Modernizm, Kapitalizm, Kitle Endüstrisi, Totalitarizm

\section{ABSTRACT}

In this study, we aim to introduce the work and criticism domains of Frnkfurt School and make a criticism of modernism within the general scope of the School. In the study are there the birth of Frankfurt School, the thinkers and general critical approaches. These include criticism of enlightenment, corruption of the mind, positivism, mass industry, capitalism and totalitarianism. The starting point of all criticism is the approaches of the members of the School. Although the study mainly focuses upon criticism of modernism by Frankfurt School, the ideas of Adorno and Horkheimer, the leading figures of the School, are discussed and outlined extensively.

Key words: Modernism, Capitalism, Mass industry, The Corruption of The Mind, Totalitarianism.
\end{abstract}

\footnotetext{
*Yrd. Doç. Dr., Erzincan Üniversitesi Sosyoloji Bölümü. ERZINNCAN (sevra.firinciogullari@erzincan.edu.tr)

DOI: 10.17498/kdeniz.334717
} 


\section{АННОТАЦИЯ}

Это исследование нацелено на критику модернизма, пользуясь общими подходами изучения и критики Франкфуртской школы. В исследовании были включены примеры мыслителей указанной школы в отношении критики модернизации. К ним относятся критика просветления, умственной коррупции, позитивизма, массового индустриализма, капитализма и тоталитаризма. Все критические моменты основываются на высказаниах членов школы по поводу модернизации. Не смотря на то, что исследование основано на критике модернизма во Франкфуртской школе, в нём, в основном, использованы широко распространённые взгляды ведущих представителей этой школы - Адорно и Хоркхаймера.

Ключевые слова: модернизм, капитализм, массовые отрасли, тоталитаризм.

"Aklın öz-yıkımı sadece tarihsel olarak tesadüfi bir olay değil, aynı zamanda Batı akılcılığının temelinde yatan tahakküme yönelmenin nihai bir sonucudur" (Seyla BENHABİB)

Modernizme ilişkin en geniş analiz ve eleştirilerin yapıldığ 1 gelenek olarak bilinen Frankfurt Okulu 1923 yılında, Frankfurt'ta kurulmuştur. 1933 yılında faşizmin yükselişe geçmesiyle Almanya'dan sürgün edildikten sonra, Amerika'ya yerleşen ancak sonrasında, Frankfurt'ta yeniden kurulan Sosyal Araştırma Enstitüsü çevresinde toplanan kimi düşünürlerin meydana getirdiği çağdaş akım ya da hareketin adı olarak bilinmektedir. Okulun kurucusu Felix Weil adında sol görüşleriyle tanınan bir doktora öğrencisidir. Rus devriminin etkisindeki bu öğrencinin kurucusu olduğu bu okulun müdürlüğünü sonraki yıllarda Max Horkheimer devralmıştır.

İlerleyen süreçte Horkheimer, Enstitü'nün uğraşacağı konuları daha açık olarak belirtir: "toplumun ekonomik hayatı ile bireyin psikolojik gelişimi ve dar anlamıyla kültürel değişmeler arasındaki karşılıklı ilişkiler (burada kültürden anlaşılan, sadece bilimin tinsel içeriği, sanat ve din değil, hukuk, adetler, moda, kamuoyu, spor, eğlenme-dinlenme biçimleri, yaşam tarzı v.b olgulardır) ... Horkheimer'le birlikte Enstitü'de yeni bir kadro oluşur. Bunlar arasında en etkili olanlar, Heidegger'in eski asistan1, felsefeci Herbert Marcuse, psikanalist Erich Fromm, edebiyat sosyolojisi alanında çalışan Leo Löwenthal ve iktisatçı Pollock'tur. Adorno'da kısa bir süre sonra Enstitü'ye girer. 1934'te Enstitü'nün ABD'ye göç etmesinden sonra bu kadroya iki siyasal bilimci katılacaktır: Otto Kirchheimer ve Franz Nuemann. Frankfurt Okulu ya da "Eleştirel Teori" olarak bilinen düşünceler toplamı, bu kadronun, en çok da Horkheimer, Adorno ve Marcuse'nin ürünüdür. (Koçak, 2013: 9, 11).

Okul, Aydınlanma düşüncesinin ve modernlik eksenli yapıların eleştirel çözümlemesini yapan, sosyal ve entelektüel yaşamın çeşitli yönlerini eleştiren, felsefe ve sosyal bilimler arasında bağ kurmaya çalışan, toplumun ekonomik temeli 
ile düşünsel yapısı arasındaki etkileşime önem veren Ortodoks olmayan Marksist yönelimli felsefe geleneğini tanımlar. Okulun önemli üyeleri arasında; Sosyolog ve sosyal psikolog olan Max Horkheimer, filozof, sosyolog ve psikolog olan Theodor Adorno, psikanalist ve sosyal psikolog olan Herbert Marcuse, edebiyat eleştirmeni Walter Benjamin, sosyolog ve filozof olan Jürgen Habermas bulunmaktadır' (Cevizci, 2005; 732)

Eleştirel Teori olarak da bilinen okulun ele aldığ konuların, modernizmin genel krizleri ve açmazları etrafında birleştiğini söylemek mümkündür. Eleştirel Okul olarak da bilinen geleneğin ele aldığ konular içinde faşizm, nazizim, burjuva toplumunun analizi, devlet yapısı, ekonomi, kapitalizm, totaliter rejimler, bilim, teknik, ideoloji, teknoloji, sanat, edebiyat, modern çağda birey ve bireyi baskı altına alan mekanizmalar gibi konular yer almaktadır.

Frankfurt Okulunun çalışma ve araştırma konuları çok çeşitlidir. İnterdisipliner bir çatıda birleşmiş bir entelektüel hareket olması itibariyle çok yönlü olan okulun çalışma alanlarını en genel kapsamda dört başlık altında toparlamak mümkündür. Modern çağın genel sorunlarının eleştirisi çerçevesinde biçimlenen söz konusu alanlar genellikle, kültür endüstrisi eleştirisi, aydınlanma eleştirisi, modernizm eleştirisi, pozitivizm eleştirisi başlıkları altında tartışılmaktadır. "2. Dünya Savaşı yıllarının Frankfurt Okulu üzerinde derin etkileri olmuştur. Savaş yılları Okul üyelerinin kuram ve eylemle ilgili düşüncelerinde radikal değişikliklere ve Enstitü üyeleri arasında parçalanmalara ve uzaklaşmalara yol açtı. Hitler'in Almanya'da iktidara gelişiyle birlikte Enstitü kapatılmış ve üyelerinin birçoğu farklı güzergahlar izleyerek ... yeniden çalışmaya başlamıştır. Adorno ve Horkheimer tarafindan savaş yıllarında yazılan ve 1947'de yayımlanan Aydınlanmanın Diyalektiği, Frankfurt Okulu'nun temel tartışma noktalarını açığa koymuştur. Frankfurt Okulu'nun başyapıtlarından olan Aydınlanmanın Diyalektiği ile birlikte Horkheimer ve Adorno'nun vurgusu kapitalizm eleştirisinden genel olarak Bat1 uygarlığı eleştirisine doğru kaymaya başlamıştır. Bu çalışmada, aklın doğadan özgürleşmesini vurgulayan modern aydınlanma ve ilerleme düşüncesinin ve pratiğinin dünyayı, insanı, doğayı bir nesneler dizesine ve tahakkümünün aygıtları olan bir alana dönüştürüldüğü tartış1lmıştır. Araçsal rasyonelliğin yükselişi Frankfurt Okulu düşünürlerine göre hiçbir biçimde gerçek özgürlüğü arttırmadı, tam tersine köle - efendi ilişkisindeki diyalektikten dolayı insanın doğa üzerindeki efendiliği giderek insanın doğayla bağlantısını yitirmesine ve toplumsal ve özneler arasındaki ilişkileri de yöneten doğal nesnelliğin buyrukları tarafından köleleştirilmesiyle sonuçlandı (Therbon, 2006: 11).

Frankfurt okulu, 1. Dünya Savaşı'yla açılıp Soğuk Savaş'la kapanan bir çağın ürünüdür. Dünya kapitalizminin bölgesel kayıplar verdiği ama yine de bunalımlardan deri değiştirerek, yeniden yapılanarak, güçlenerek çıktığı bir çağdır bu. "Can çekişen kapitalizm" teorilerinin, gerçekten can çekişmekte olan eski liberal kapitalizmle birlikte silinip gittiği bir çağ. Dünya değişmemiş, ama rekabetçi kapitalizm örgütlü tekelci kapitalizme dönüşmüştür. Kendisiyle birlikte emek- 
sermaye ilişkilerini, işçi hareketini, devrimci teoriyi de dönüştürerek (Therborn, 2006:7)

\section{Pozitivizm Eleștirisi}

Eleştirel Teori'nin pozitivizme yaklaşımı, sosyal bilimlerin, doğa bilimlerinin yöntem ve tavrını benimsemesi bu yönüyle insan dünyasının karmaşıklığını ve çok yönlülügünü görememesi, modern dönemde bireyin yitimi, farkl1l1kların silikleşmesi, tek tipleşme, kitle kültürü ile sistemin zihinlerde meşrulaştırılması, faşizm dolayısıyla Aydınlanma'nın kendini yok edişi paralelinde ilerler. Özünde Eleştirel Teori'nin bu tartışmaları aydınlanmaya ve onun yarattığı tahakküm içeren tüm kurumlara yöneliktir. Özellikle Aydınlanma'nın Diyalektiği'nde Adorno ve Horkeimer'ın üzerinde durduğu ana tema, "Aydınlanma'nın kendini imha etmesi", yani, olguların, eleştirel, olumsuzlayıcı bir şekilde ele alınması olarak alınan aklın, pozitivist bilim felsefesi ve bilimsel düşünceyle ulaşılan 'yanlış bedahat' yoluyla yok edilmesi. Bu modern bilimsel bilinç, insanlığın hakikaten insansal bir duruma gelme yerine, yeni bir tür barbarlığa batmasının' bir sonucu olarak kültürel çöküşün esas kaynağı şeklinde ele alınmalıydı. Böylece kitabın ilk kısmında pozitivizmin eleştirisine gidilmişti ve bu eleştiri, burada bir bilim ve teknoloji eleştirisiyle ilişkilendirildi ki, bu da, bunların 'ideolojiler' olarak (yeni egemenlik biçimlerinin kurulmasını mümkün kılan ve yardımcı olan ideolojiler) ele alınmasını öndelemektedir" (Bottomore, 1997: 18).

Pozitivizm eleştirisi, (ya da daha iyi bir deyimle 'bilimciliğin'), yeni bir egemenlik biçimi, geç kapitalist ya da daha geniş olarak, yirminci yüzyılın ileri endüstriyel toplumlarının niteliği olarak 'bilimsel ve teknolojik rasyonalitenin' eleştirel bir belirlenimiyle karışmıştı. Bu Frankfurt Okulu'nun [...] ideoloji eleştirisi üzerine büyüyen vurgusunun bir yanıyd1. 1944'de değin Horkheimer ve Adorno şöyle tartışıorlardı: Bacon tam olarak kendisinden sonra gelen bilimin ruhunu yakaladı. İnsan zekası ve şeylerin doğası arasında hayal ettiği mutlu evlilik ataerkil bir evlilikti: Hurafeleri yenilgiye uğratan zeka, büyüsü bozulmuş doğaya hükmetmelidir. Bilgi, ki güçtür, ne varlıkları köleleştirmesine ne de dünyanın efendilerine yumuşak başlı boyun eğişinde bir sınır tanır (Therborn, 2006: 29). "Özerkliği kalmayan akıl bir araç haline gelmiştir... Akıl bütünüyle toplumsal sürece boyun eğmiştir. Aklın araçsal değeri, doğa ve insan üzerinde egemenlik kurulmasında oynadığı rol, tek ölçüt durumundadır (Horkheimer, 2013: 67)

Frankfurt Okulu'nun pozitivizm eleştirisinin en genel kapsamda, akı1, aydınlanma, doğanın nesneleştirmesi, faşizm, totalitarizm, Nazizm ve kitle endüstrisi üzerinden biçimlendiği söylenebilir. Okulun ileri gelenlerinin pozitivizme yönelik eleştirileri ve bu perspektifle biçimlenmiş yaklaşımlarının modernizmin akılcılığının yarattığı yıkıcılığa yönelik olduğunu belirtmek mümkündür. Genel anlamda yükselen akıl çağında, aşırı akılcılaşmanın köklerindeki yozlaşmayı modern çağa dönük eleştirilerinin tümüne yaydıkları da söylenebilir.

Eleştirel teorisyenlere göre faşizmin de köklerini bulduğu bu tahakküm süreci, doğanın tüketilmesi ve boyun eğdirilmesi düşüncesinden başlayarak, insan ilişkilerine, yani insanın hem eşyaya hem doğaya hem de insana davranış 
biçimlerinde görünmeye başlar ve doruk noktasını faşist diktatörlüklerde bulur. Faşizm, düşünce tarihinde Bacon'la başlayan tahakkümün kültür ve bilgiyle olumladığı aydınlanmanın amacının da gerçeğidir. Ana suçlu, pazar ve üretim ilişkileri değil, ama doğa bilimleri ve onun epistemelojideki ampirist kopyasıdır (Therborn, 2006: 37).

Pozitivizm ve ampirizm eleştirisi toplumsal teori için alternatif bir epistemoloji ve metodoloji geliştirme girişimi, Horkeimer'ın 1937'deki geleneksel eleştirel teori denemesinden, 1969 'daki pozitivizm tartışmasına kadar, yalnızca bir temel sunmakla kalmayıp, Franfurt Okulu'nun otuz yıllık toplum(sal) teorisinin geniş bir parçasını oluşturur... Okulun eleştirisi üç ayrı boyuta sahiptir:

*Illkin pozitivizm toplumsal hayatın doğru bir şekilde kavramsallaştııılması ve anlaşılmasını sağlamayan ve sağlayamayan, yetersiz ve yanlış yönlendirici bir yaklaşımdır.

*İkincisi, pozitivizm yalnızca var olana katılmakla var olan siyasal düzeni kutsallaştırır, radikal herhangi bir değişikliği engeller ve siyasal dinginciliğe sürükler.

*Üçüncüsü pozitivizm içsel olarak yeni bir egemenlik biçimini, yani 'teknokratik egemenliği' destekleme ve üretmeye bağımlıdır ve bu süreçlerde temel bir etmen olmaktadır" (Bottomorre, 1997: 29).

\section{Modernizm Eleștirisi, Frankfurt Okulu ve Theodor Ludwig Wiesengrund Adorno}

Frankfurt Okulu içinde modernizme yönelik bilinen en derin analiz Theodor Adorno'ya aittir. Adorno okul içinde çalışma alanları en geniş filozoflardan biri olarak bilinmekle birlikte modern çağa özgü krizi bir çok yönüyle ele alan ve temellendiren kişi olarak da bilinmektedir.

Adorno, dinini değiştirip Katolikleşerek Almanlaşmış Yahudi bir şarap tüccarı olan Oscar Wiesengrund ile Cenovalı bir aileden olan profesyonel ses sanatçısı Maris Calvelli - Adorno'nun oğlu olarak ... 11 Eylül 1903'te dünyaya gelmiş̧ir. Adorno, ses sanatçısı olan annesi ve kendileriyle birlikte kalan piyanist teyzesi Agathe'den müzik eğitimi almıştır. On beş yaşındayken, Alman klasik felsefesi üzerine çalışmaya ve haftada bir gün de Kant'1 okumaya başlamış... 1921 'de Frankfurt'un yeni kurulmuş olan ve yenilikçi olarak adını duyuran Johann Wolfgang Goethe Üniversitesine başlamıştır. 1922 yılında kendisinden sekiz yaş büyük olan Horkheimer ile tanışır. Toplumbilim, psikoloji ve müzikle ilgili dersler alır ve üç yıl sonra, Kantçı düşünür Hans Cornelius yönetiminde yaptığı, Edmund Husserl üzerine olan doktora çalışmasını bitirir ve felsefe doktoru unvanını alır. Adorno hakkında Marcuse, "Adorno tam bir dahi idi, ... hayatımda felsefe, sosyoloji, müzik, sanat ve... her şeyde onun kadar geniş bilgili onun kadar konusuna hakim bir insan görmedim... Konuşmaya başladığı zaman, başka hiçbir düzeltiye gerek kalmadan, konuştuğu şeyi yazılı metin diye dizgiye verip yayınlayabilirdiniz" demektedir (Veysal, 2009: 314).Adorno'nun en bilinen eserleri: "Olumsuz Diyalektik”, "Kültür Endüstrisi”, "Otoriter Kişilik”, "Estetik Teorisi”, “Aydinlanmanin Diyalektiği”" (Cevizci, 2005; 17). 
Çalışmaları, sanat, müzik, ideoloji, popüler kültür, pozitivizm gibi çok farklı ve geniş alanlara yayılsa da, Adorno'nun, okulun da genel duruşu çerçevesinde bir Aydınlanma ve modernizm eleştirisini ele aldığ 1 söylenebilir. Onun tüm çalışma alanları, modern dönemin açmazlarını tartışan ve eleştiren bir zemine yaslanır.

Genel olarak modern döneme ilişkin eleştirileri okulun geleneğinden bağımsız olmaksızın, aydınlama, pozitivizm, ideoloji ve totalitarizm paralelinde bir seyir izler. Adorno, Aydınlanmanın hedeflediği evrensellik iddialarının, kuşatııı tek tipleştirme mantığının karşısına bireyi koyarak özellikle farklılıklar üzerinde durur. Adorno'ya göre, Aydınlanmanın temel argümanlarından biri olan özne nesne karşıtlığı başlı başına bir sorun teşkil etmektedir.

\subsection{Adorno, Pozitivizm Eleştisi ve Özne- Nesne Karşıtlığı}

Adorno'ya göre, birbirinden farklı olan ve birbirine hiçbir şekilde indirgenemeyen özne ve nesneden her biri diğeri tarafindan kurulur. Onlar birbirlerine özsel bir tarzda bağlanmış, karşılıklı olarak bağımlı yapılardır. Bunu göremeyen birçok felsefe, birtakım yanlış özdeşlikler kurmak suretiyle ya nesneyi özneye ya da özneyi nesneye indirger. Ona göre, kurucu öznelliğe veya öznenin kavramlarının dünyayı meydana getirdiği düşüncesine yönelik vurgusuyla öznelcilik klasik ifadesini burjuva idealizminde bulur [...]Frankfurt Okulu'nun diğer düşünürleri gibi, pozitivizmin, dünyanın oluşturulmasında öznelliğin yaratıcı ve aktif gücünü - yani, tarih, kültür ve toplumu - kavrayamadığını, dünyayı bitmiş bir realite, ikinci bir doğa olarak kabul ettiğini... belirten Adorno, özne ve nesne probleminde çağdaş epistemolojinin süre giden yanlışını, yani Descartes'tan beri özne ve nesnenin birbirinden bütün bütüne ayrı tutulması anlayışını eleştirir. Adorno, gerçekliğin tek bir nokta-i nazardan, statik bir bakış açısından kavranamayacağını toplumsal kültürel gelişmenin dışında, tarihin bir bütün olarak yargılanacağı standart bir duruş olamayacağını öne sürer. Ona göre özne, nesnenin belirleyenlerini kendi ölçülerine göre düşünüp indirgeyerek, nesnenin niteliklerinin ne olduğunu unutarak olumsuzlamaktadır. İnsanın en başlangıçtaki doğa içinde konumlanmışlığı (yani onunla bir ve aynı olduğu) düşünme ve eylem içerisinde yadsınıp unutulduğunda, doğanın da tahakküm altına alınması başlamış olmaktadır. Demek ki daha başlangıçtan beri doğanın özne tarafından tek yanlı (insan merkezli) bir egemenlik altına alınması, iktidarın da içinden doğduğu toplumsal hiyerarşi ve denetlemeyle birlikte ilerlemektedir. Öznenin nesneye egemenliği, felsefi anlamıyla pozitivizm (araçsal bir keşif etkinliğinde) ... kendini açıkça göstermektedir ... Özne ile nesnenin farklılığının yoksanması, yani özdeş oluşları, düşünmenin kaybı anlamına gelmektedir. Adorno, bir yandan özne ile nesnenin mutlak ayrılığına öte yandan nesneyle öznenin özdeşliğine ... karşıdır. Adorno, ne özne ve nesnenin birbirinden ayrı şeyler olduğunu fark edemeyen birlik anlayışının ne de bunların bir araya gelmesi olanaksız karşıt şeyler olduğu anlayışının uyumluluk ya da birlik içinde yer alamayacağını; tersine, birbirinden farklılıkları olmaları nedeniyle ayrı oldukları özneyle nesne arasındaki karşılıklı iletişime bağlı olduğu anlaşılmadıkça, objektif bir kavram olarak iletişimin bile var olamayacağ d düşüncesindedir... Adorno'nun önemli tehditlerden biri saydığı şey, çeşitlilikten doğan zenginliği ve 
farklılığı baskı altına almanın, görünüşte öznellik karşıtı, bilimsel açıdan nesnel olan ve indirgemecilik diye tanınan benzeştirici düşüncedir. Adorno, evrensel ve tikelin anti-tezlerinin de hem gerekli hem de aldatıcı olduğunu, bunlarının her birinin ötekinin varlığına gereksinim duyduğunu, tikel olanın ancak betimlendiğinde var olduğu ve evrensel olabildiğini; evrensel olanınsa, ancak tikel olanın betimlenmesi olduğu zaman var olabildiğini ve bu yüzden de tikel olduğunu belirterek, bunların her ikisinin hem kendileri hem kendileri olmadığını [...] vurgulamaktadır (Veysal, 2009: 315, 316).

\section{Adorno ve Pozitivizm Eleştirisinde Bireyin ve Doğanın Tahakküm Altına Alınışı}

Adorno'nun tavrı genel olarak Aydınlanmanın evrenselliğine, kuşatıcıllı̆ına ve bütünlük iddiasına da bir eleştiri şeklindedir. Ayrıca onun bu yaklaşımı Aydınlanmanın temelleri üzerine inşa edilen modern dönemin insana ve doğaya karşı tutumuna, insan ve doğada var olan farklılıkları göremeyen yaklaşımına ve doğayı tahakküm altına almayı hedefleyen tavrına karşı da ciddi bir eleştiri olarak okunabilir. Aklı yücelten Aydınlanmanın çıkış noktasından oldukça fazla uzaklaştığını vurgulayan Adorno bunun kanıtlarını özellikle yabancılaşma temelinde ele alır. "Doğal dünyanın insan tarafından manipule edilmesi, sayısallaştırılıp tasnif edilen alanlar içinde algılanması şeyleştirmedir... Adorno, bir bütün içindeki öğelerin bir kısmının, bir diğerine üstün tutulamayacağı, birinin asli ötekinin ise tabi olan olmayacağı, böyle bir düşüncenin kendi karşıtını yaratacağı [...] düşüncesindedir [...] İnsan doğadan bağımsızlaşma ile ilkin doğaya egemen olmuş ve insanın doğaya egemen olması ile insanın türdeşi üzerinde egemenliği de zorunlulukla başlamıştır... Adorno, doğanın bağımlılığından insanın özgürleşmesinin tarihsel hareketi olarak düşünülen ilerlemenin geride bıraktığ şeyin sadece bir çöküş olduğunu düşünmektedir... Ona göre [...] insanlar egemenliklerindeki artışın bedelini, egemenlik altına aldıkları şeylerden yabancılaşarak ödemektedirler. Aydınlanmanın şeylere karşı tutumu, diktatörün insanlara karş1 tutumu gibidir" (Veysal, 2009: 372, 373, 375).

Minima Moralia adlı eserinde Adorno, teknolojinin gelişimiyle insanın yabancılaşma sürecini ve bunun yaşamlarına yansıma biçimini şu şekilde örneklendirmektedir:

"Teknoloji, jestlerle birlikte insanların dakikleşmesine, kesinleşmesine ve hunharlaşmasına yol açıyor, insan hareketlerini her türlü duraksamadan, düşüncelilikten ve edepten arındırıyor. Onları nesnelerin amansız ve denebilirse tarih dışı taleplerine bağımlı kılıyor. Böylece, söz gelimi bir kapıyı yavaşça, sessizce ama sıkıca kapatma yeteneği de yitiriliyor. Arabaların ve buzdolaplarınınkiler çarpılarak kapatılmak zorunda, kimi kapılarsa kendiliklerinden kapanıyor, içeri girenleri arkalarına bakmama ve kendilerini kabul eden evi korumama gibi nezaketsizliklere mahkum ederek. Yeni insan tipini anlamak istiyorsak, onu çevresindeki nesneler dünyasının sürekli etkisine maruz kalan, sisteminin en derin noktalarında bile oradan izler taşıan bir varlık olarak düşünmemiz gerekir. Artık içeri doğru açılacak pencerelerin yerinde sadece sağa 
sola itilecek sürgülü camların olması özne için ne demektir? Yumuşak kapı mandallarının yerinde döner tokmakların olması, avluların ortadan kalkması, sokak kapısının önündeki birkaç basamağın ve bahçe duvarının yok olması acaba nasıl etkilemiştir onu? Sırf motorunun gücünden ötürü, sokakların haşaratını, yayaları, çocukları ve bisikletleri ezip geçme isteğini bir kez olsun içinde duymamış sürücü var mıdır? Makinelerin kendi kullanıcılarından talep ettikleri hareketler de Faşist zorbalıkta gördüğümüz o vahşi sert, huzursuz savrukluk ve dengesizliği içermiştir çoğu zaman. Yaşantının kuruyup gitmesinin bir nedeni de şu olmalı:

Nesnelerin saf işlevsellik yasasının buyruğuna girmekle aldıkları biçim, onlarla teması sadece işleticiliğe indirgemekte ve gerek insanların hareket özgürlüğünde gerekse nesnelerin özerkliğinde herhangi bir fazlalığa, eylem anının içinde tüketilemeyecek ve yaşantının çekirdeği olarak varlığını sürdürecek herhangi bir artığa izin vermemektir (Adorno, 2005: 42).

Adorno ve Horkheimer'e göre, burjuva meta ekonomisinin yaygınlaşmasıyla birlikte, hesap eden aklın güneşi, mitin karanlık ufkunu aydınlatmıştır; şimdi bu güneşin buz gibi ışınları altında yeni barbarlık tohumları olgunlaşmaktadır. Egemenlik altında her zaman mitin çekim alanına giren insan emeği, egemenliğin baskısı altında hep mit tarafından uzaklara taşınmaktadır. Aydınlanmanın özünün, egemenlikten kaçınamama olduğu görülmektedir. İnsanlar her zaman doğaya boyun eğme ya da doğayı kendilerine boyun eğdirme seçeneğiyle karşı karşıya kalmaktadır (Veysal, 2009: 319).

Adorno ve Horkheimer'ın çalışmalarında sıkça rastlanan ve kitle endüstrisi, üreten burjuva meta ekonomisive aklın yozlaşması kavramları üzerine olan görüşleri birbiri üzerinden temellenir. Buna göre modern çağda akıl yozlaşmış, doğayı bir nesne konumuna indirgemiş ve insanı da sayısal bir veriye dönüştürmüştür. Sanayi çağının mekanik ruhu, bu sayısal tasnifi içeren burjuva ekonomisinin kitlesel üretimi ve endüstrisini yaratmıştır. Doğayı bir nesneye indirgeyen modern akıl, insanı da bir sayısal veri gibi görüp nesneleştirmiştir. bunun sonucunda kitle endüstirisi ve onun ideolojik mimarı bir ideoloji tam da bu tavrıyla aklın yıkımını gerçekleştirmiştir. İnsanı yücelten aydınlanma çağında akıl, insanı kitleler içinde bir veri olarak sayısallaştırarak yozlaşmıştır. $\mathrm{Bu}$ durum aydınlanmanın hedefini tepetaklak eden, aklın kendi yıkımından başka bir şey değildir. Zira insan kendini tasnif eden bir ekonomik düzen üretmiş ve aklını bu ekonomik düzen için kullanarak kendini aldatmayı seçmiştir. "Kültür endüstrisinin toplam etkisi Aydınlanma karşıtı bir etkidir; bu etkide Horkheimer'ın ve benim belirttiğimiz gibi, Aydınlanma, yani doğa üzerinde giderek artan bir biçimde teknik hakimiyet kurma, bir kitle aldatmacasına, bilincin zincire vurulmasının aracina dönüşüyor. Bu etki, özerk, bağımsız bilinçli yargılarda bulunan ve kendi kararlarını veren bireylerin ortaya çıkmasını engelliyor. Oysa bu bireyler, yalnızca reşit kişilerde varlığını koruyabilen ve kendini geliştirebilen demokratik bir toplumun ön koşuludurlar. Kitleler, haksız yere, yukarıdan kitleler olarak aşağılanıyorsa, onların kitlelere dönüşüp aşağılanmalarında ve insanların, çağın üretici güçlerinin izin 
verdiği olgunlaşmaya erip özgürleşmelerinin engellenmesinde, kültür endüstrisinin sorumluluğu hiç de azımsanamaz (Adorno, 2011: 119).

Aydınlanma'nın bu temelleri üzerine inşa edilen insan bilimlerine de eleştiri yönelten Adorno, bütün içinde farklılıkların görülemeyeceği ve bu perspektifle de sosyal gerçekliğin anlaşılamayacağını özellikle vurgular. Söz konusu vurguyu ise "bütün hakiki olmayandır" önermesi ile temellendirir.

"Toplum bilimlerinin doğa bilimlerinin gelişmişlik düzeyine gelip gelemeyeceğini, yöntemlerinin doğa bilimlerine benzeyip benzemeyeceğini konulaştıran "Alman Sosyolojisinde Pozitivizm Tartışması" içinde [...] Adorno, aslında sosyolojiye atfedilen bilgisizliğin bu alana konu olan gerçekliğin özünün yanlış anlaşılmasından kaynaklanan bir suçlama olduğunu, sosyolojide bilgisizliğin gerçek değil görünüş olduğunu göstermeye çalışarak konuya girmektedir. Adorno'ya göre, toplumsal gerçeklik bir önerme dizgesi ile dile getirilemez... Gerçeklik, yani toplum, ne tutarlı, ne yalın ne de yansız olarak kategorilere dayalı bir anlatıma izin verir. Tam tersine, toplumsal gerçekliğin alt yapısı nesne olarak toplumdur ve bu çıkarımsal mantığın kategoriler dizgesini oluşturur. Dolayısıyla toplumsal nesnenin üstünde tasarlanan çıkarımsal bir mantık bu nesnenin bilgisini sağlayamaz... Toplum çelişkilerle dolu ama yine de bilinebilir, aynı zamanda ussal ve usdışı, parçalara ayrılmış, kör bir doğa ama yine de bilince dayanan bir yapıdadır. Bu nedenle sosyolojinin yöntemi bu özelliklere ayak uydurmalıdır, yoksa salt çelişkilerden kaçınma çabasından dolayı öngörülen yöntem en ölümcül çelişki olan kendi yapısı ile nesnenin yapısı arasında bir çelişkiye düşer. Toplumbilimin açıklık ve kesinlik ideali peşine düşmesi, toplumsal gerçekliğin algılanmasını engelleyebilir (Veysal, 2005: 374).

Adorno, toplumsal gerçekliği kavramaya elverişli yaklaşım savlarını en genel kapsamda şu şekilde değerlendirmektedir. "1-) Toplumsal bütünün yaşamı bu bütünün öğelerinin üstünde ve onlardan bağımsız değildir.2-) Toplumsal bütün, bireysel öğelerine dayanarak kendi kendinin üretir ve geliştirir.3-) Bu bütün, kendi öğelerinin gerek işbirliğinden gerekse birbirleriyle çatışmasından ayrı tutulamaz.4-) Genel olarak da hiçbir öğe, yalnızca kendi işlevlerine dayanarak ve bireysel öğelerinin etkinliğinden kaynaklanmış olan bütünden ayrı olarak anlaşılamaz. 5-) Dizge ile birey, birbirinin karşılıkları sayllıp ancak bu karşılıklar çerçevesinde kavranabilir. Adorno, empirik toplumbilimlerin yaşadığımız koşulların insanlaştırılmasına katkıda bulunabileceğine inanmaz. Toplumbilimlerdeki gelişmelerin sonucu olarak ortaya çıkan gelişme, insanın denetlenebilirliğini kolaylaştırmakta ve buna hizmet etmektedir. Toplumbilimlerini bu tek yanlılığa ayartan da, doğa bilimlerinde ortaya çıkan yüzyılın başındaki olağanüstü gelişmelerdir. Ama aynı zamanda asıl neden, rasyonelliğin özgül felsefi anlaşı1ışıdır. Bu felsefi kavramsallaştırma, düzen, zihin ya da metottur kanaatini ileri sürer. Eylemde başarı ölçü olmuştur, dolayısıyla teorinin içeriğini belirler. Her yaklaşım araçsallığı öne çıkarmakta, "iyi pratik"ten kasıt, yalnızca problem çözme olarak anlaşılmaktadır. Bu problem de [...] bilimin belirlediği problemleri içerir. Ancak bilimler toplumsal sorunlar karşısında kördürler. Ancak toplumsal 
gerçekliğin "bilimsel" bakış açısından bağımsız olarak kurulamayacağını düşünen Adorno, toplumun kendini resmi bilimsel düzene uydurduğunu, bu modelin baştan sona bir hiyerarşik yapısı olduğunu vurgular. Toplumbilimler, ardında sınıf farklılıklarının toplumsal gerçekliğinin görünmez olduğu yüzeysel fenomenlerle uğraşırlar. Sonuç olarak, toplumsal bilimler ilkin, metod ve sınanan öznenin özgün birliğini yeniden kurmalı ve özgül sorulara yanıt aramalıdır. Adorno'ya göre felsefe ve toplumbilimleri birleşmelidir. "Ona göre bilimsel hakikat fikri, hakiki bir toplumun hakikatinden ayrılamaz" (Veysal, 2005: 374, 375).

Ona göre felsefi anlama, hakikati farklı cephelerden görme olanağı sunduğu için önemlidir. Felsefe kendini tanımlamalı, hem gerçekliği anlamak hem de onu açılamak için yani "hem metin olmak hem de metni deşifre etmek için" çaba göstermelidir. Adorno, felsefenin farklı cephelerden bakan perspektiflerinin daha sonra birleştirilerek, gerçekliği daha iyi anlayabilmek için kullanılabileceğinin altını çizer.

Adorno Minima Moralia adlı eserinde felsefenin ne yapması gerektiği konusunda şunlara yer verir: "Umutsuzluk karşısında sorumlu bir biçimde sürdürülebilecek tek felsefe, her şeyi kurtarılmanın bakış açısından görünecekleri biçimiyle düşünme çabasıdır. Kurtarılışın saçtığı 1şıktan başka 1şığ 1 yoktur bilginin; başka her şey kurgudur, tekrardır, sadece tekniktir. Perspektifler oluşturulmalı, öyle perspektifler ki dünyayı yerinden uğratsın, yadırgı kılsın, onu bütün çatlaklar, kırışıklıkları, yara izleriyle birlikte bir gün mesihin ışığında görüneceği gibi sefalet ve çarpıklıklarıyla göstersin. Keyfiliğe ya da cebre kaymadan, sadece nesnelerle temas yoluyla böyle perspektiflere ulaşmak - düşüncenin görevi sadece budur" (Adorno, 2005: 153).

\section{Sonuc}

Frankfurt Okulu, interdisipliner alanda modernizme yönelik en geniş çalışmaların, yaklaşım ve eleştirilerin gerçekleştirildiği bir entelektüel geleneğin adıdır. Okulun yaklaşımı modernizmin açmazlarını pek çok noktadan ele almayı ve analiz etmeyi olanaklı kılmaktadır. Özellikle modern akıl çağında aklın yozlaşmasıyla başlayan yabancılaşmayı ele almış olmaları önemlidir. Zira aklın yozlaşmasıyla başlayan ve insanın, önce doğaya, sonrasında kendi türüne karşı yabancılaşması, okulun interdisipliner çalışmaları içinde derinlikle analiz edilmiştir.

Horkheimer ve Adorno'yu okulun diğer üyelerinden ayıran nokta çalışmalarında aklın yozlaşmasıyla başlayan ve bütün çağın ruhuna yayılan [kendi deyimleriyle barbarlıkla sonuçlanan] süreci insan - doğa, insan-eşya ve insan-insan ilişkileri temelinde incelikle analiz etmiş olmalarıdır. Ortaçağ epistemesinin kırılması sonrasında modern insanda başlayan en büyük değişim aklını yüceltişi sonrasında yaşamının tümünün ruhsuz ve mekanik bir organizasyonla kuşatmasıyla başlamıştır. Doğadan kopuk olmayan ortaçağ insanının aksine modern insan doğadan kopmuş ve ona karşı sevgisinin yerini bir korku almıştır. Söz konusu korku doğayı bir nesne gibi görüp onu tahakküm altına alma çabasını beraberinde getirmiştir. Doğaya karşı bu mekanik, ruhsuz, akılcı ve zorba tutum insanın tüm eylem ve ilişkilerine yansımış ve yaşamını kuşatmıştır. İnsanın doğaya karşı kendini 
akılcı bir özne olarak konumlandırması, onu manipüle edilmesi gereken bir nesne gibi görmesi, yaşamındaki her ilişkide aynı hoyratlığı üretmesine neden olmuştur. Teknolojiyi ve akılla yapılan her eylemi yücelten insan aklı, kendi türüne karşı da aynı acımasız tutum içine girmiş, bu tutum nazi soykırımını üreten bir barbarlığı beraberinde getirmiştir. Adorno'ya göre faşizmi üreten ve totalitarizmi tırmandıran şey aynı akılcı ve duygudan arını insan tipinin eylemlerinin sonucudur.

Ortaçağ'da ruhaniliğin yozlaşması akılla aşılmış ancak aklın aşırı yüceltilmesi, doğadan ve duygularından arını daha barbar bir insan tipini yaratmışır. Aklın yozlaşması üretim sistemi olan kapitalizmi, siyasi alanda faşizmi, bilimsel alanda pozitivizmi, tüketim alanda ise kitle kültürüne bağlı hoyratça tüketerek kendini yok eden bir sistemin oluşumunu beraberinde getirmiştir.

Adorno, bu süreci aşacak çıkış yolunun bireyden geçtiğinin altını çizer. Görüşleri içinde çok keskin bir umutsuzluk ve karamsarlık hissedilse de, bu kadar karanlık bir sistemi üreten modern insanın kendini yeniden kurarak çıkabileceğini vurgular. Ona göre birbirinden farklı perspektifleri üreten insan aklının görevi, artık bu çürümüş acımasız döngüyü tüm çarpıklıklarıyla ortaya koymak olmalıdır. Bu noktada kapalı gibi görünen sistemde bireyin bilincinin karanlığı yırtacağının altını çizer. Bu çerçevede yozlaşmış modern aklın bu yozlaşmayı aşacak gücü ve özü içinde barındırdığını da vurgulamıştır. Ona göre tüm bu yozlaşmaya neden olan akıl aynı karanlığı parçalayacak gücü de taşımaktadır.

\section{KAYNAKLAR}

ADORNO, L, T, Minimia Moralia, Çeviri: Orhan Koçak,Ahmet Doğukan, Metis Yayınları, 2005, İstanbul

ADORNO, T, W, "Kültür Endüstrisi Kültür Yönetimi”, "Kültür Endüstrisine Genel Bir Bakış", Çeviren: Mustafa Tüzel, İletişim Yayınları, İstanbul

BENHABIB, S, "Modernlik ve Eleştirel Kuramın Çıkmazları" Frankfurt Okulu, Çeviri:

BOTTOMORE, T, "Frankfurt Okulu”, Vadi Yayınları, 1997, Ankara

CEVIZCİ, A, "Frankfurt Okulu”, Felsefe Sözlüğü, Paradigma Yayınları, 2005, İstanbul İstanbul

CEVİZCI, A, “Adorno” Felsefe Sözlügü, Paradigma Yayınları, 2005,

EMRE Bağçe, Doğu Batı Yayınları, 2006, Ankara

HORKHEIMER, M, "Akll Tutulması", "Araçlar ve Amaçlar", Çeviri: Orhan Koçak, Metis Yayınları, 2013, İstanbul

KOÇAK, O, "Akll Tutulması", "Horkheimer ve Frakfurt Okulu, Çeviri: Orhan Koçak, Metis Yayınları, 2013, İstanbul

THERBORN, G, "Frankfurt Okulu”, Frankfurt Okulu, Çeviri: Emre Bağce, Doğu Batı Yayınları, 2006, Ankara

VEYSAL, Ç, “T. L. V. Adorno”, 1900'den Günümüze Büyük Düşünürler, Etik Yayınları, 2009, İstanbul. 